Check for updates

Cite this: RSC Adv., 2019, 9, 20892

\title{
Novel polymeric derivatives of betulin with anticancer activity $\dagger$
}

\author{
Daria Niewolik, ${ }^{a}$ Katarzyna Krukiewicz, ${ }^{\text {ad }}$ Barbara Bednarczyk-Cwynar, ${ }^{\text {b }}$ \\ Piotr Ruszkowskic and Katarzyna Jaszcz (D) *a
}

\begin{abstract}
In order to provide novel polymeric biomaterials for chemotherapeutic purposes, in this paper we described the synthesis and the characterization of the physicochemical properties of a betulin-based polyanhydride exhibiting anti-cancer effects. The polyanhydride was obtained by a melt polycondensation of a disuccinate betulin (3,28-di-O-succinyl betulin), and was thoroughly characterized through ${ }^{1} \mathrm{H} N M R$ and ${ }^{13} \mathrm{C}$ NMR spectroscopies, correlation spectroscopy, heteronuclear single quantum correlation, size exclusion chromatography, differential scanning calorimetry and FT-IR spectroscopy. It was confirmed, that the obtained polyanhydride undergoes hydrolytic degradation, releasing disuccinate betulin as a degradation product. Polyanhydride of a disuccinate betulin was tested for cytostatic activity against a wide range of cancer cell lines (HeLa, MCF-7, A-549, U-87MG, KB and HepG2), proving its efficiency in inhibiting the growth of selected cancer cells. To realize the concept of an easily administrated drug release system, polyanhydride was fabricated in a form of micro- $(1-30 \mu \mathrm{m})$ and nanospheres ( 400 $\mathrm{nm})$ by using an emulsion solvent evaporation method. The micro- and nanospheres were characterized by SEM.
\end{abstract}

Received 4th May 2019

Accepted 24th June 2019

DOI: $10.1039 / \mathrm{c} 9 \mathrm{ra03326b}$

rsc.li/rsc-advances betulin. Nevertheless, this problem can be solved by providing betulin in a polymeric form, e.g. in a shape of micro- or nanoparticles, which, in turn, can be easily administrated by injection or inhalation. In literature, however, there are only several reports describing the fabrication of polymeric forms of betulin, including polyesters, polyurethanes and polyethylene oxide conjugates. $^{9-12}$ These materials exhibit high porosity and are used mainly in non-biological applications, e.g. for gas adsorption studies. In these syntheses betulin, containing two hydroxyl groups, is used as a renewable diol. These hydroxyl groups, however, can be also easily transformed into carboxyl ones, e.g. in a reaction with succinic anhydride. Disuccinate betulin (DBB), formed in this way, was found to exhibit biological activity in terms of anti-cancer, anti-leishmania, hypolipidemic, fungicidal, bactericidal and antiviral effects, including Epstein-Barr virus and HIV. ${ }^{5,13-17}$ On the other hand, DBB containing two carboxylic groups is an excellent raw material to obtain polyanhydrides, a class of surface-degradable polymers. Due to their properties, such as easy tunable release kinetics and lack of toxicity, polyanhydrides are mainly used in medicine, both as drug carriers and biomaterials. ${ }^{18}$ For the best of our knowledge, so far there are no literature reports describing the synthesis of betulin-based polyanhydrides.

The aim of this work is to study the synthesis of a polyanhydride formed from disuccinate betulin and its fabrication into a form of micro- and nanoparticles. To fully characterize this polymer, we used nuclear magnetic resonance (NMR) spectroscopy, infrared (IR) spectroscopy, gel chromatography (GPC) and differential scanning calorimetry (DSC). Hydrolytic

$\dagger$ Electronic supplementary information (ESI) available. See DOI: 10.1039/c9ra03326b 
degradation of polyDBB in physiological conditions was also investigated. In order to determine the anti-cancer activity of disuccinate betulin and polyDBB, these materials were tested for cytotoxicity against a wide range of cancer cell lines, including HeLa, MCF-7, A-549, U-87MG, KB and HepG2. The micro- and nanospheres were further characterized using optical microscopy and scanning electron microscopy (SEM).

\section{Experimental}

\subsection{Materials}

Betulin > 95\% (Natchem), succinic anhydride 99\% (SigmaAldrich), pyridine (min 99.5\%, Chempur), acetic anhydride (POCh S.A.), DMSO (Chempur), trichloroacetic acid (Chempur), acetic acid (Chempur), Tris buffer, sulforhodamine, poly(vinyl alcohol) $\left(M_{\mathrm{w}}=88000 \mathrm{~g} \mathrm{~mol} \mathrm{~m}^{-1}, 88 \%\right.$ hydrolyzed) (ACROS Organics), methylene chloride (Chempur) were used as supplied.

\subsection{Methods}

Infrared (FT-IR) spectra were recorded by means of a PerkinElmer Spectrum Two Spectrometer. NMR spectra were obtained using a Varian $600 \mathrm{MHz}$ spectrometer in $\mathrm{CDCl}_{3}$ with TMS as an internal standard. Molecular weight of the polyanhydride was determined in methylene chloride by gel-permeation chromatography (GPC) using Agilent Technologies Infinity 1260 chromatograph equipped with a refractive index detector and calibrated with polystyrene standards. Thermal analyses were performed using a $822^{\mathrm{e}}$ DSC Mettler Toledo differential scanning calorimeter. Samples were tested in temperature range from $-60{ }^{\circ} \mathrm{C}$ to $350{ }^{\circ} \mathrm{C}$ at a heating rate of $10{ }^{\circ} \mathrm{C} \mathrm{min}^{-1}$. Shape and size of microspheres were estimated using optical microscope DELTA Optical ME 100 and PHAMIAS 2003 v.1.3 B software. The morphological characterization of micro- and nanospheres was carried out using a Phenom ProX scanning electron microscope (SEM).

\subsection{Synthesis of disuccinate betulin (DBB)}

The synthesis of DBB was carried out, as follows. $4.43 \mathrm{~g}(10.0$ $\mathrm{mmol}$ ) of betulin was dissolved under heating in $100 \mathrm{~mL}$ of dried pyridine. $10.0 \mathrm{~g}$ (100 mmol) of succinic anhydride was added and the obtained solution was refluxed during 8 hours. The solution was cooled and poured into $500 \mathrm{~mL}$ of $5 \% \mathrm{HCl}$. The resulted precipitate was filtered off, washed with water to neutral $\mathrm{pH}$ and dried. The obtained amorphous powder was dissolved in ethanol under heating, boiled with active carbon and filtered. The product was precipitated with water, filtered off, washed again with water and dried. Yield: 92\%, mp 106$110{ }^{\circ} \mathrm{C}$, ESI-MS $\mathrm{m} / \mathrm{z} 665,4[\mathrm{M}+\mathrm{Na}]^{+}$(calcd for DBB: 642, 87)

IR: $v=2941 \mathrm{~cm}^{-1}\left(\mathrm{~m}, v_{\mathrm{C}-\mathrm{H}}\right), 2844 \mathrm{~cm}^{-1}\left(\mathrm{w}, v_{\mathrm{C}-\mathrm{H}}\right), 1724-$ $1706 \mathrm{~cm}^{-1}\left(\mathrm{~s}, v_{\mathrm{C}=\mathrm{O}}\right), 1310-1155 \mathrm{~cm}^{-1}\left(v_{\mathrm{C}-\mathrm{O}}\right) ; 1603 \mathrm{~cm}^{-1}$, $982 \mathrm{~cm}^{-1}, 880 \mathrm{~cm}^{-1}\left(\mathrm{~m}, v_{\mathrm{C}=\mathrm{C}}\right)$.

${ }^{1} \mathrm{H}$ NMR (600 MHz, $\left.\mathrm{CDCl}_{3}, \delta\right): 4.68\left(1 \mathrm{H}, \mathrm{d}, J=1.7 \mathrm{~Hz}, \mathrm{C}_{29}-\mathrm{H}_{\mathrm{a}}\right)$; $4.59\left(1 \mathrm{H}, \mathrm{d}, J=0.2 \mathrm{~Hz}, \mathrm{C}_{29}-\mathrm{H}_{\mathrm{b}}\right) ; 4.50\left(1 \mathrm{H}, \mathrm{t}, J=7.9 \mathrm{~Hz}, \mathrm{C}_{3}-\mathrm{H}_{\alpha}\right)$; $4.30\left(1 \mathrm{H}, \mathrm{d}, J=11.0 \mathrm{~Hz}, \mathrm{C}_{28}-\mathrm{H}_{\mathrm{a}}\right) ; 3.88\left(1 \mathrm{H}, \mathrm{d}, J=11.0 \mathrm{~Hz}, \mathrm{C}_{28^{-}}\right.$ $\mathrm{H}_{\mathrm{b}}$ ); 2.72-2.64 (6H, m, HOOC- $\mathrm{CH}_{2}-\mathrm{CH}_{2}-\mathrm{COO}-$, $-\mathrm{OOC}-\mathrm{CH}_{2}-$
$\mathrm{CH}_{2}-\mathrm{COOH}$ ); $2.64-2.58$ (2H, m, HOOC- $\left.\mathrm{CH}_{2}-\mathrm{CH}_{2}-\mathrm{COO}-\right) ; 2.42$ $\left(1 \mathrm{H}, \mathrm{dt}, J=5.7\right.$ and $\left.10.3 \mathrm{~Hz}, \mathrm{C}_{19}-\mathrm{H}\right) ; 1.68\left(3 \mathrm{H}, \mathrm{s}, \mathrm{C}_{30}-\mathrm{H}_{3}\right) 1.95$ $\left(1 \mathrm{H}, \mathrm{m}, \mathrm{C}_{21}-\mathrm{H}_{\mathrm{a}}\right) ; 1.81\left(1 \mathrm{H}, \mathrm{d}, \mathrm{C}_{16}-\mathrm{H}_{\mathrm{a}}\right) ; 1.74\left(1 \mathrm{H}, \mathrm{t}, \mathrm{C}_{22}-\mathrm{H}_{\mathrm{a}}\right) ; 1.69$ $\left(3 \mathrm{H}, \mathrm{s}, \mathrm{C}_{30}-\mathrm{H}_{3}\right)$; 1.68-1.56 (7H, m, C $\mathrm{C}_{15}-\mathrm{H}_{\mathrm{a}}, \mathrm{C}_{1}-\mathrm{H}_{\mathrm{a}}, \mathrm{C}_{12}-\mathrm{H}_{\mathrm{a}}, \mathrm{C}_{13}-$ $\left.\mathrm{H}_{\mathrm{a}}, \mathrm{C}_{2}-\mathrm{H}_{\mathrm{a}, \mathrm{b}}, \mathrm{C}_{18}-\mathrm{H}\right) ; 1.51\left(1 \mathrm{H}, \mathrm{m}, \mathrm{C}_{6}-\mathrm{H}_{\mathrm{a}}\right) ; 1.45-1.35\left(5 \mathrm{H}, \mathrm{m}, \mathrm{C}_{6}{ }^{-}\right.$ $\left.\mathrm{H}_{\mathrm{b}}, \mathrm{C}_{11}-\mathrm{H}_{\mathrm{a}}, \mathrm{C}_{21}-\mathrm{H}_{\mathrm{b}}, \mathrm{C}_{7}-\mathrm{H}_{\mathrm{a}, \mathrm{b}}\right) ; 1.28\left(1 \mathrm{H}, \mathrm{d}, \mathrm{C}_{9}-\mathrm{H}\right) ; 1.26-1.17(2 \mathrm{H}$, $\left.\mathrm{m}, \mathrm{C}_{11}-\mathrm{H}_{\mathrm{b}}, \mathrm{C}_{16}-\mathrm{H}_{\mathrm{b}}\right) ; 1.13-1.04\left(3 \mathrm{H}, \mathrm{m}, \mathrm{C}_{22}-\mathrm{H}_{\mathrm{b}}, \mathrm{C}_{12}-\mathrm{H}_{\mathrm{b}}, \mathrm{C}_{15}-\mathrm{H}_{\mathrm{b}}\right)$; $1.03\left(3 \mathrm{H}, \mathrm{s}, \mathrm{C}_{25}-\mathrm{H}_{3}\right) ; 0.97\left(3 \mathrm{H}, \mathrm{s}, \mathrm{C}_{27}-\mathrm{H}_{3}\right)$; 0.94-0.92 (1H, m, C ${ }_{1}-$ $\left.\mathrm{H}_{\mathrm{b}}\right) ; 0.86-0.82\left(3 \times 3 \mathrm{H}, 3 \times \mathrm{s}, \mathrm{C}_{26}-\mathrm{H}_{3}, \mathrm{C}_{23}-\mathrm{H}_{3}, \mathrm{C}_{24}-\mathrm{H}_{3}\right) ; 0.78(1 \mathrm{H}$, d, $\left.\mathrm{C}_{5}-\mathrm{H}\right)$.

${ }^{13} \mathrm{C}$ NMR (150 MHz, $\left.\mathrm{CDCl}_{3}, \delta\right): 178.0\left(\mathrm{C}_{\mathrm{q}}, \mathrm{C}(\mathrm{O}) \mathrm{OH}\right) ; 172.37$, $171.77\left(\mathrm{C}_{\mathrm{q}}, \mathrm{C}(\mathrm{O}) \mathrm{O}\right) ; 150.09\left(\mathrm{C}_{\mathrm{q}}, \mathrm{C}-20\right) ; 109.88\left(\mathrm{CH}_{2}, \mathrm{C}-29\right) ; 81.55$ (CH, C-3); $63.19\left(\mathrm{CH}_{2}, \mathrm{C}-28\right), 55.39$ (CH, C-5); 50.24 (CH, C-9); 48.76 (CH, C-18), 47.71 (CH, C-19); $46.42\left(\mathrm{C}_{\mathrm{q}}, \mathrm{C}-17\right) ; 42.69\left(\mathrm{C}_{\mathrm{q}}\right.$, $\mathrm{C}-14) ; 40.87\left(\mathrm{C}_{\mathrm{q}}, \mathrm{C}-8\right) ; 38.34\left(\mathrm{CH}_{2}, \mathrm{C}-1\right) ; 37.82\left(\mathrm{C}_{\mathrm{q}}, \mathrm{C}-10\right) ; 37.58$ (CH, C-13); $37.04\left(\mathrm{C}_{\mathrm{q}}, \mathrm{C}-4\right)$; $34.40\left(\mathrm{CH}_{2}, \mathrm{C}-22\right)$; $34.07\left(\mathrm{CH}_{2}, \mathrm{C}-7\right)$; $31.23\left(\mathrm{CH}_{2} \mathrm{C}(\mathrm{O}) \mathrm{OH}\right) ; 29.62\left(\mathrm{CH}_{2}, \mathrm{C}-21\right) ; 29.53\left(\mathrm{CH}_{2}, \mathrm{C}-16\right)$; $29.02\left(\mathrm{CH}_{2} \mathrm{C}(\mathrm{O}) \mathrm{O}\right) ; 27.88\left(\mathrm{CH}_{3}, \mathrm{C}-23\right) ; 27.00\left(\mathrm{CH}_{2}, \mathrm{C}-15\right) ; 25.13$ $\left(\mathrm{CH}_{2}, \mathrm{C}-12\right) ; 23.58\left(\mathrm{CH}_{2}, \mathrm{C}-2\right) ; 20.80\left(\mathrm{CH}_{2}, \mathrm{C}-11\right) ; 19.08\left(\mathrm{CH}_{3}, \mathrm{C}-\right.$ $30) ; 18.15\left(\mathrm{CH}_{2}, \mathrm{C}-6\right) ; 16.51\left(\mathrm{CH}_{3}, \mathrm{C}-25\right) ; 16.14\left(\mathrm{CH}_{3}, \mathrm{C}-26\right)$; $16.02\left(\mathrm{CH}_{3}, \mathrm{C}-24\right) ; 14.80\left(\mathrm{CH}_{3}, \mathrm{C}-27\right)$.

DEPT: $6 \times \mathrm{CH}_{3}, 16 \times \mathrm{CH}_{2}, 6 \times \mathrm{CH}$.

\subsection{Prepolymer and polymer synthesis}

Polyanhydride was obtained by a two-step melt polycondensation of betulin disuccinate according to the procedure described earlier. ${ }^{\mathbf{1 9 , 2 0}}$ Betulin disuccinate $(5 \mathrm{~g})$ was refluxed in acetic anhydride (1:10, w/v) under nitrogen flow for $40 \mathrm{~min}$. After this time, the excess of acetic anhydride and acetic acid formed in the reaction were removed under vacuum. The remaining diacyl derivative of disuccinate betulin (prepolymer) was heated at $150{ }^{\circ} \mathrm{C}$ for $2 \mathrm{~h}$ with constant stirring under vacuum $(0.1 \mathrm{~mm} \mathrm{Hg})$ and nitrogen. PolyDBB in a form of a solid, amorphous material was obtained with a yield of over $90 \%$. The obtained polymer was stored in a freezer.

IR: $v=2941 \mathrm{~cm}^{-1}\left(\mathrm{~m}, v_{\mathrm{C}-\mathrm{H}}\right), 2844 \mathrm{~cm}^{-1}\left(\mathrm{w}, v_{\mathrm{C}-\mathrm{H}}\right), 1827 \mathrm{~cm}^{-1}$ $\left(\mathrm{m}, v_{\mathrm{C}=\mathrm{O}}\right), 1724 \mathrm{~cm}^{-1}\left(\mathrm{~s}, v_{\mathrm{C}=\mathrm{O}}\right), 1034 \mathrm{~cm}^{-1}\left(v_{\mathrm{C}-\mathrm{O}}\right)$.

${ }^{1} \mathrm{H}$ NMR (600 MHz, $\left.\mathrm{CDCl}_{3}, \delta\right): 4.69\left(1 \mathrm{H}, \mathrm{d}, \mathrm{C}_{29}-\mathrm{H}_{\mathrm{a}}\right) ; 4.59(1 \mathrm{H}$, $\left.\mathrm{d}, \mathrm{C}_{29}-\mathrm{H}_{\mathrm{b}}\right), 4.50\left(1 \mathrm{H}, \mathrm{t}, \mathrm{C}_{3}-\mathrm{H}_{\alpha}\right) ; 4.30\left(1 \mathrm{H}, \mathrm{d}, \mathrm{C}_{28}-\mathrm{H}_{\mathrm{a}}\right) ; 3.89(1 \mathrm{H}, \mathrm{d}$, $\mathrm{C}_{28}-\mathrm{H}_{\mathrm{b}}$ ); 2.84-2.74 (4H, m, -OCOOC- $\left.\mathrm{CH}_{2}-\mathrm{CH}_{2}-\mathrm{COO}-\right)$; $2.74-$ 2.62 (4H, m, -OCOOC- $\left.\mathrm{CH}_{2}-\mathrm{CH}_{2}-\mathrm{COO}-\right)$; $2.42\left(1 \mathrm{H}, \mathrm{td}, \mathrm{C}_{19}-\mathrm{H}\right)$; 2.18 (end groups); $1.96\left(1 \mathrm{H}, \mathrm{m}, \mathrm{C}_{21}-\mathrm{H}_{\mathrm{a}}\right) ; 1.82\left(1 \mathrm{H}, \mathrm{d}, \mathrm{C}_{16}-\mathrm{H}_{\mathrm{a}}\right)$; $1.76\left(1 \mathrm{H}, \mathrm{t}, \mathrm{C}_{22}-\mathrm{H}_{\mathrm{a}}\right)$; $1.68\left(3 \mathrm{H}, \mathrm{s}, \mathrm{C}_{30}-\mathrm{H}_{3}\right)$; $1.67-1.54\left(7 \mathrm{H}, \mathrm{m}, \mathrm{C}_{15^{-}}\right.$ $\left.\mathrm{H}_{\mathrm{a}}, \mathrm{C}_{1}-\mathrm{H}_{\mathrm{a}}, \mathrm{C}_{12}-\mathrm{H}_{\mathrm{a}}, \mathrm{C}_{13}-\mathrm{H}_{\mathrm{a}}, \mathrm{C}_{2}-\mathrm{H}_{\mathrm{a}, \mathrm{b}}, \mathrm{C}_{18}-\mathrm{H}\right) ; 1.51\left(1 \mathrm{H}, \mathrm{m}, \mathrm{C}_{6}-\right.$ $\left.\mathrm{H}_{\mathrm{a}}\right)$; 1.45-1.35 (5H, m, C $\left.6-\mathrm{H}_{\mathrm{b}}, \mathrm{C}_{11}-\mathrm{H}_{\mathrm{a}}, \mathrm{C}_{21}-\mathrm{H}_{\mathrm{b}}, \mathrm{C}_{7}-\mathrm{H}_{\mathrm{a}, \mathrm{b}}\right) ; 1.29$ $\left(1 \mathrm{H}, \mathrm{d}, \mathrm{C}_{9}-\mathrm{H}\right)$; 1.26-1.17 (2H, m, $\left.\mathrm{C}_{11}-\mathrm{H}_{\mathrm{b}}, \mathrm{C}_{16}-\mathrm{H}_{\mathrm{b}}\right)$; 1.13-1.04 (3H, $\left.\mathrm{m}, \mathrm{C}_{22}-\mathrm{H}_{\mathrm{b}}, \mathrm{C}_{12}-\mathrm{H}_{\mathrm{b}}, \mathrm{C}_{15}-\mathrm{H}_{\mathrm{b}}\right) ; 1.02\left(3 \mathrm{H}, \mathrm{s}, \mathrm{C}_{25}-\mathrm{H}_{3}\right) ; 0.97$ (3H, s, $\left.\mathrm{C}_{27}-\mathrm{H}_{3}\right) ; 0.94-0.92\left(1 \mathrm{H}, \mathrm{m}, \mathrm{C}_{1}-\mathrm{H}_{\mathrm{b}}\right) ; 0.88-0.80\left(9 \mathrm{H}, \mathrm{s}, \mathrm{C}_{26}-\mathrm{H}_{3}\right.$, $\left.\mathrm{C}_{23}-\mathrm{H}_{3}, \mathrm{C}_{24}-\mathrm{H}_{3}\right) ; 0.78\left(1 \mathrm{H}, \mathrm{d}, \mathrm{C}_{5}-\mathrm{H}\right)$.

${ }^{13} \mathrm{C}$ NMR (150 MHz, $\left.\mathrm{CDCl}_{3}, \delta\right): 171.93\left(\mathrm{C}_{\mathrm{q}}, \mathrm{C}(\mathrm{O}) \mathrm{O}\right) ; 167.96\left(\mathrm{C}_{\mathrm{q}}\right.$, $\mathrm{C}(\mathrm{O}) \mathrm{OC}(\mathrm{O})) ; 150.03\left(\mathrm{C}_{\mathrm{q}}, \mathrm{C}-20\right)$; $109.93\left(\mathrm{CH}_{2}, \mathrm{C}-29\right) ; 81.74(\mathrm{CH}, \mathrm{C}-$ 3); $63.36\left(\mathrm{CH}_{2}, \mathrm{C}-28\right), 55.40$ (CH, C-5); 50.27 (CH, C-9); $48.81(\mathrm{CH}$, $\mathrm{C}-18), 47.71$ (CH, C-19); $46.43\left(\mathrm{C}_{\mathrm{q}}, \mathrm{C}-17\right) ; 42.71\left(\mathrm{C}_{\mathrm{q}}, \mathrm{C}-14\right) ; 40.91$ $\left(\mathrm{C}_{\mathrm{q}}, \mathrm{C}-8\right) ; 38.36\left(\mathrm{CH}_{2}, \mathrm{C}-1\right) ; 37.86\left(\mathrm{C}_{\mathrm{q}}, \mathrm{C}-10\right)$; 37.61 (CH, C-13); $37.07\left(\mathrm{C}_{\mathrm{q}}, \mathrm{C}-4\right)$; $34.52\left(\mathrm{CH}_{2}, \mathrm{C}-22\right)$; $34.11\left(\mathrm{CH}_{2}, \mathrm{C}-7\right)$; 30.38$30.32\left(\mathrm{CH}_{2} \mathrm{C}(\mathrm{O}) \mathrm{OC}(\mathrm{O})\right) ; 29.72\left(\mathrm{CH}_{2}, \mathrm{C}-21\right) ; 29.57\left(\mathrm{CH}_{2}, \mathrm{C}-16\right)$; 
$28.62\left(\mathrm{CH}_{2} \mathrm{C}(\mathrm{O}) \mathrm{O}\right) ; 27.97\left(\mathrm{CH}_{3}, \mathrm{C}-23\right) ; 27.04\left(\mathrm{CH}_{2}, \mathrm{C}-15\right) ; 25.17$ $\left(\mathrm{CH}_{2}, \mathrm{C}-12\right) ; 23.65\left(\mathrm{CH}_{2}, \mathrm{C}-2\right) ; 20.81\left(\mathrm{CH}_{2}, \mathrm{C}-11\right) ; 19.14\left(\mathrm{CH}_{3}, \mathrm{C}-\right.$ 30); $18.16\left(\mathrm{CH}_{2}, \mathrm{C}-6\right) ; 16.53\left(\mathrm{CH}_{3}, \mathrm{C}-25\right) ; 16.14\left(\mathrm{CH}_{3}, \mathrm{C}-26\right)$; $16.04\left(\mathrm{CH}_{3}, \mathrm{C}-24\right) ; 14.76\left(\mathrm{CH}_{3}, \mathrm{C}-27\right)$.

\subsection{Hydrolytic degradation of polyDBB}

Hydrolytic degradation experiments were performed in a phosphate buffer solution of $\mathrm{pH} 7.4$ (PBS) or in distilled water ( $\mathrm{pH}$ 5.5) at $37^{\circ} \mathrm{C}$. The hydrolytic degradation was monitored by both the mass loss of the test samples and the content of anhydride groups. PolyDBB powder samples (approximately $0.1 \mathrm{~g}$ ) were placed in the weighed filters. Then, the filters with polyDBB were placed in glass vials containing $15 \mathrm{~mL}$ of PBS or distilled water, respectively. The vials were incubated at $37^{\circ} \mathrm{C}$ for various time (from $1 \mathrm{~h}$ to 14 days). After incubation, the buffer or water were decanted, lyophilized and tested by ${ }^{1} \mathrm{H}$ NMR to examine degradation products. The remaining samples were rinsed with distilled water, dried to constant weight in a vacuum oven, weighed to the nearest $0.0001 \mathrm{~g}$ and tested by ${ }^{1} \mathrm{H}$ NMR to calculate the content of anhydride groups. The mass loss was defined as follows:

$$
\Delta m=\frac{m_{1}-m_{2}}{m_{1}} \times 100 \%
$$

where $m_{1}$ represents the weight of the dry sample before degradation and $m_{2}$ represents the weight of dry sample after degradation at different time intervals.

The ratio of anhydride groups to the sum of anhydride and ester groups in the polyanhydride $(A / A+E)$ was calculated using the formula:

$$
A / A+E=I_{\mathrm{SAd}} /\left(I_{\mathrm{SAc}}+I_{\mathrm{E}}\right)
$$

where $I_{\mathrm{SAc}}$ represents the intensity of proton signals of the methylene group in the anhydride moiety with a chemical shift $(\delta)$ of $2.82-2.77 \mathrm{ppm}$ and $I_{\mathrm{E}}$ represents the intensity of the proton signals of the methylene group in the ester moiety with a chemical shift $(\delta)$ of $2.74-2.64 \mathrm{ppm}$.

\subsection{Stability of polyDBB}

In addition to the polyDBB hydrolytic degradation study, the degradation rate of the polyanhydride in air at room temperature was also investigated. For this purpose, polyDBB samples were placed in a glass vessel and left in the air. Every few days, samples were tested by ${ }^{1} \mathrm{H}$ NMR to calculate the content of anhydride moieties to the sum of the anhydride and ester moieties. Calculations were carried out in the same manner as in the case of hydrolytic degradation.

\subsection{Cell cultures}

KB, HeLa, MCF-7, and Hep-G2 cells were obtained from the European Collection of Cell Culture (ECACC) supplied by Sigma Aldrich. A-549, U-87, and HDF cells were purchased from the American Type Culture Collection (ATCC) through LGC Standards (Lomianki).
KB, Hep-G2 and U-87 cells were cultured in EMEM medium while HeLa cells were grown in RPMI 1640 medium, A-549 cells in F-12K medium, MCF-7 cells in DMEM medium and HDF cells in Fibroblasts Growth Medium. Each medium was supplemented with $10 \%$ fetal bovine serum, 1\% L-glutamine and 1\% penicillin/streptomycin solution. All cultures were maintained at $37{ }^{\circ} \mathrm{C}$ in a humidified atmosphere containing $5 \% \mathrm{CO}_{2}$.

\subsection{Cytostatic activity of DBB and polyDBB}

For the determination of the cytostatic activity of test compounds, the protein-staining sulforhodamine B (SRB) assay was employed. The SRB method has been assessed by the National Cancer Institute (USA) as suitable for the in vitro antitumour screening. ${ }^{22}$ The SRB assay estimates cell densities based on the measurement of cellular protein content. For the SRB assay, $100 \mu \mathrm{L}$ of diluted cell suspension containing approximately $10^{4}$ cells was added to the wells of 96-well plates. After $24 \mathrm{~h}$, when a partial monolayer was formed, the supernatant was aspirated and $100 \mu \mathrm{L}$ medium containing test compounds (DBB and polyDBB) at six different concentrations $\left(0.1,0.2,1,2,10\right.$ and $\left.20 \mu \mathrm{g} \mathrm{mL}^{-1}\right)$ was added to the cells. Stock solutions of test compounds were prepared in DMSO and the concentration of DMSO in the assay did not exceed $0.1 \%$ which was found to be nontoxic to applied cell lines. After incubation for $72 \mathrm{~h}, 25 \mu \mathrm{L}$ of $50 \%$ trichloroacetic acid was added to each well and the plates were incubated for $1 \mathrm{~h}$ at $4{ }^{\circ} \mathrm{C}$. After that, the plates were washed with distilled water to remove traces of medium and were air-dried. Then, the dried plates were stained with $100 \mu \mathrm{L} 0.4 \% \mathrm{SRB}$ (prepared in $1 \%$ acetic acid) for $30 \mathrm{~min}$ at room temperature. Unbound dye was removed by rapid washing with $1 \%$ acetic acid and the plates were air-dried overnight. Finally, the protein-bound dye was dissolved in $100 \mu \mathrm{L}$ of $10 \mathrm{mM}$ unbuffered Tris and the absorbance was read at $490 \mathrm{~nm}$.

\subsection{Microspheres and nanospheres preparation}

In order to provide polyDBB in a form suitable for controlled drug release systems, attempts were made to obtain polymer micro- and nanospheres. Microspheres were prepared according to previous reports. ${ }^{19,21}$ In short, the polymer was dissolved in methylene chloride $\left(20 \mathrm{~mL}\right.$, concentration $\left.50 \mathrm{mg} \mathrm{mL}^{-1}\right)$ and emulsified with $400 \mathrm{~mL}$ of aqueous solution $(1.0 \% \mathrm{w} / \mathrm{w})$ of poly(vinyl alcohol) (PVA 88\% hydrolyzed, MW = $88000 \mathrm{~g} \mathrm{~mol}^{-1}$ ) using ULTRA-TURRAX T18 homogenizer, for $30 \mathrm{~s}$. The speed of homogenizer was 3000 or $18000 \mathrm{rpm}$, respectively. The emulsion was then stirred with a magnetic stirrer at $1100 \mathrm{rpm}$ at room temperature for $3 \mathrm{~h}$ to evaporate the organic solvent. After that, microspheres were collected by centrifugation at $5000 \mathrm{rpm}$ for $5 \mathrm{~min}$, washed 3 times with distilled water, lyophilized and stored in a freezer. Nanospheres were obtained by the same method as microspheres, using an ultrasonic homogenizer Omni Ruptor 250 (50\% pulses, 50\% power, $60 \mathrm{~s}$ ).

Size and size distribution of particles were estimated using optical microscope, according to the procedure described earlier. ${ }^{21}$ The diameters of at least 100 particles were measured on each of the photomicrograph (magnification $100 \times$ and $400 \times)$. Then, number average diameters $\left(D_{\mathrm{n}}\right)$ and volume 
average diameters $\left(D_{\mathrm{v}}\right)$, standard deviation (S) and dispersity index $\left(D_{\mathrm{v}} / D_{\mathrm{n}}\right)$ were calculated $\left(D_{\mathrm{n}}=\sum N_{\mathrm{i}} D_{\mathrm{i}} / \sum N_{\mathrm{i}}, D_{\mathrm{v}}=\sum N_{\mathrm{i}} D_{\mathrm{i}}{ }^{4} /\right.$ $\sum N_{\mathrm{i}} D_{\mathrm{i}}{ }^{3}$, where $N_{\mathrm{i}}$ is the number of particles having diameter $D_{\mathrm{i}}$ ). The morphological characterization of microspheres was carried out using a Phenom ProX scanning electron microscope (SEM).

\section{Results and discussion}

\subsection{PolyDBB synthesis and characterization}

Betulin disuccinate (DBB) was synthesized by esterification of succinic anhydride and betulin. The reaction was carried out in dried pyridine, following a modified procedure described earlier by Sun et al. ${ }^{13}$ and Tian et al. ${ }^{23,24} \mathrm{DBB}$ was isolated in high yields (92\%), and its chemical structure was confirmed by IR and NMR spectroscopies and ESI-MS. The obtained results were consistent with the literature data provided earlier., ${ }^{13,23,24}$

PolyDBB was obtained by melt a polycondensation of betulin disuccinate with the use of acetic anhydride (Fig. 1), and its physicochemical properties were thoroughly evaluated by a number of analytical and spectroscopic techniques.

The polymer was found to be insoluble in water, ethanol, acetone, diethyl ether and hexane, but could be dissolved in chloroform, methylene chloride, toluene, THF and partially in DMSO. Thermal properties of obtained polymer were investigated using the DSC method. Comparative DSC thermograms of polyDBB before and after the heat treatment under a nitrogen atmosphere are shown on Fig. 2. The DSC analysis indicated that the polyDBB melts at a high temperature of $320^{\circ} \mathrm{C}$. The determined heat of melting was equal to $108 \mathrm{~J} \mathrm{~g}^{-1}$. In the first run of heating, exothermal transition with the peak at $238{ }^{\circ} \mathrm{C}$, was also observed and attributed to the crystallization process.
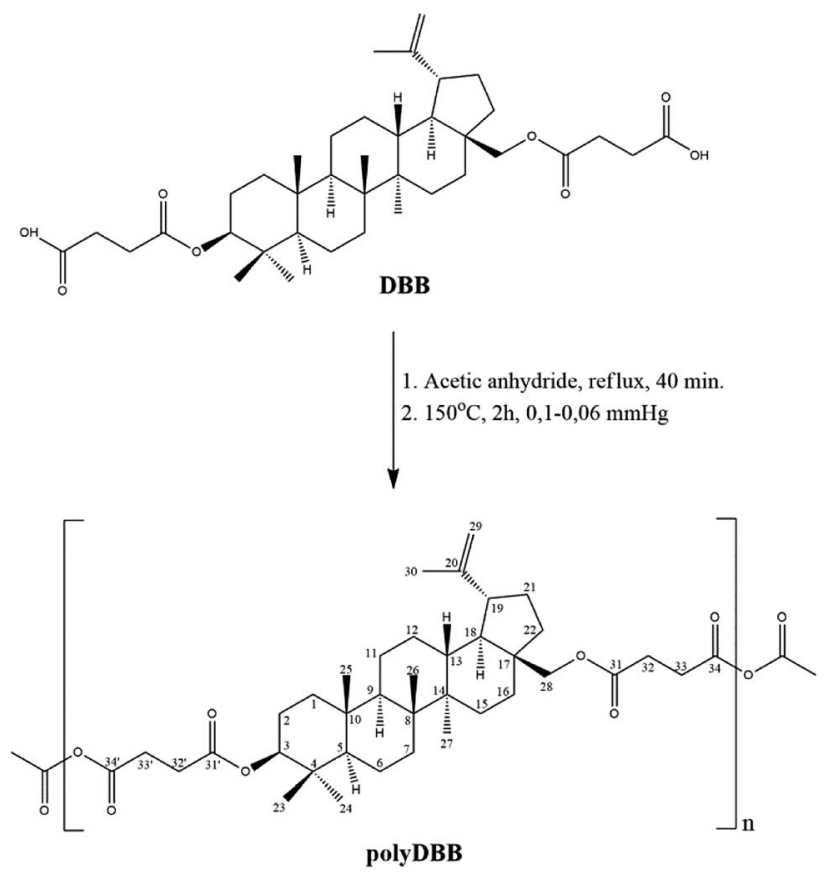

Fig. 1 Reaction scheme of the synthesis of polyDBB.

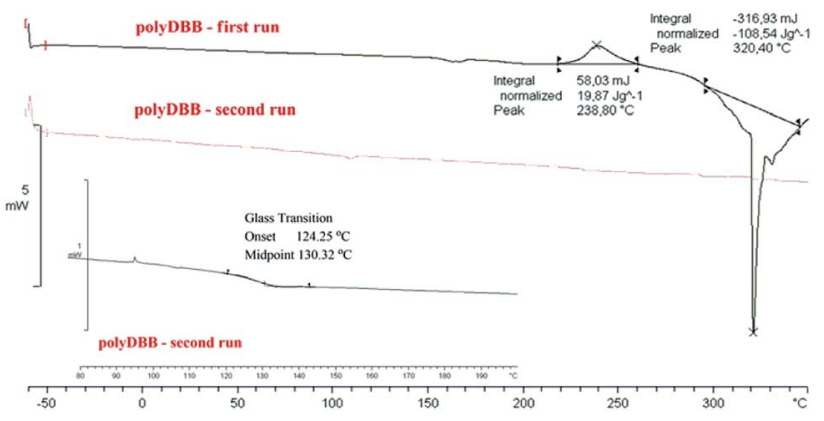

Fig. 2 DSC thermograms of polyDBB.

After being cooled down to room temperature, the melt of polyDBB did not crystallize in DSC experiments. In the second run of heating neither melting nor crystallization was observed. Melted polyDBB does not crystallize after cooling and remains glassy under ambient conditions, showing glass transition temperature $\left(T_{\mathrm{g}}\right)$ equal to $124^{\circ} \mathrm{C}$.

The molecular weight of polyDBB was calculated from ${ }^{1} \mathrm{H}$ NMR and determined by GPC (Table 1). The GPC chromatogram of polyDBB made directly after synthesis has shown only one fraction with relatively low dispersity (Fig. 3). The $M_{\mathrm{n}}$ of the obtained product was approx. $8500 \mathrm{~g} \mathrm{~mol}^{-1}$, which corresponded to a polymer consisting of 13 repeating units. A good correlation was found between $M_{\mathrm{n}}$ determined by GPC and the one calculated from ${ }^{1} \mathrm{H}$ NMR (Table 1). However, when the GPC analysis was made a few days after the synthesis, or the polymer solution for analysis was stored for too long, the appearance of the second fraction was observed in the GPC chromatograms. The molecular weight of the second fraction corresponded approximately to DBB which indicates a hydrolytic degradation of the polymer during its storage, which occurs with the release of free DBB.

To determine the exact structure of polyDBB, IR (Fig. 4), ${ }^{1} \mathrm{H}$ NMR (Fig. 5), ${ }^{13}$ C NMR (Fig. 6), HSQC (Fig. 7) and COSY spectra were made. A successful polyDBB synthesis was confirmed by the formation an anhydride bond. The presence of two peaks in the carbonyl region of the IR spectrum of polyDBB at $1724 \mathrm{~cm}^{-1}$ and $1827 \mathrm{~cm}^{-1}$ confirmed the formation of anhydride bonds.

In ${ }^{1} \mathrm{H}$ NMR spectra of polyDBB (Fig. 5), the signals at $\delta=$ 2.74-2.64 ppm and at $\delta=2.82-2.77 \mathrm{ppm}$ are observed, which could be assigned to methylene protons close to ester (E) and anhydride (A) groups, respectively. The presence of the signal at $\delta=2.84-2.77 \mathrm{ppm}$ in ${ }^{1} \mathrm{H}$ NMR spectrum indicates the formation of the polymer. The molecular weight of polyDBB was calculated

Table 1 Molecular weight of polyDBB calculated from ${ }^{1} \mathrm{H}$ NMR and determined by GPC

\begin{tabular}{lllll}
\hline & & \multicolumn{2}{l}{$\begin{array}{l}\text { Molecular weight } \\
\text { (GPC) }\end{array}$} & \\
\cline { 3 - 4 } & $M_{\mathrm{n}}\left({ }^{1} \mathrm{H}\right.$ NMR $)$ & $M_{\mathrm{n}}$ & $M_{\mathrm{w}}$ & $M_{\mathrm{w}} / M_{\mathrm{n}}(\mathrm{GPC})$ \\
\hline polyDBB & 8225 & 8496 & 24939 & 2.94
\end{tabular}




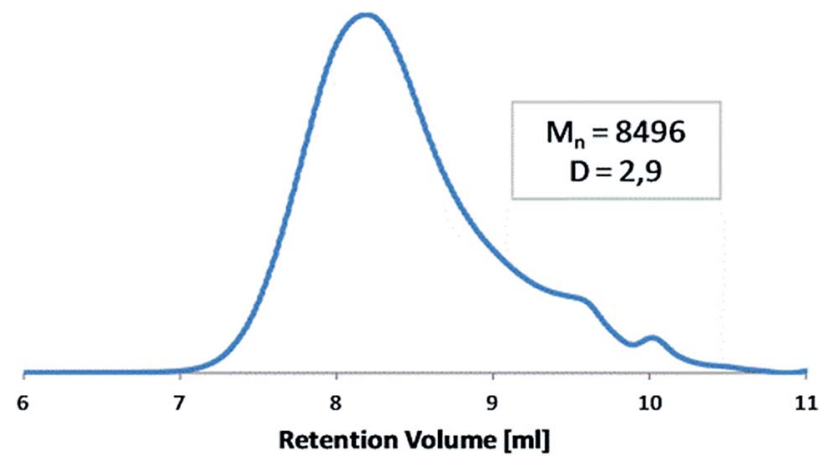

Fig. 3 Representative GPC chromatogram of polyDBB.
A

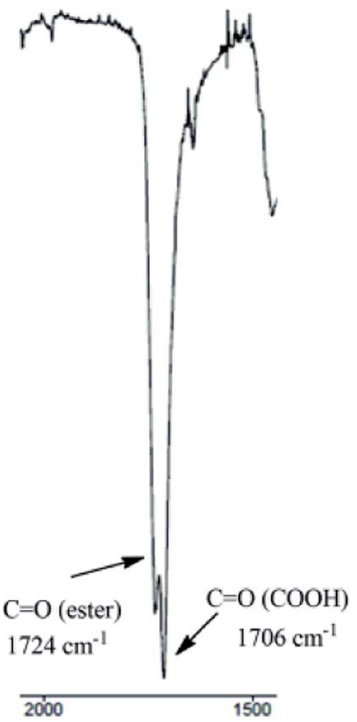

B

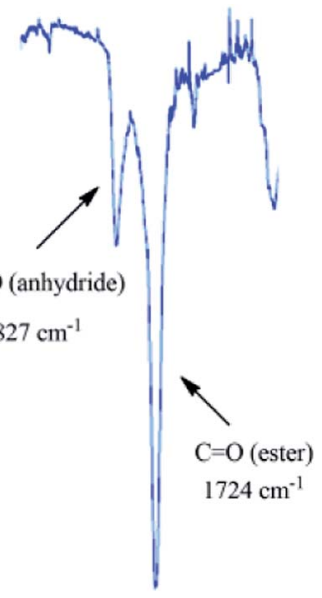

$\overline{2000}$

1500
Fig. 4 IR spectra (carbonyl region) of DBB (A) and polyDBB (B).

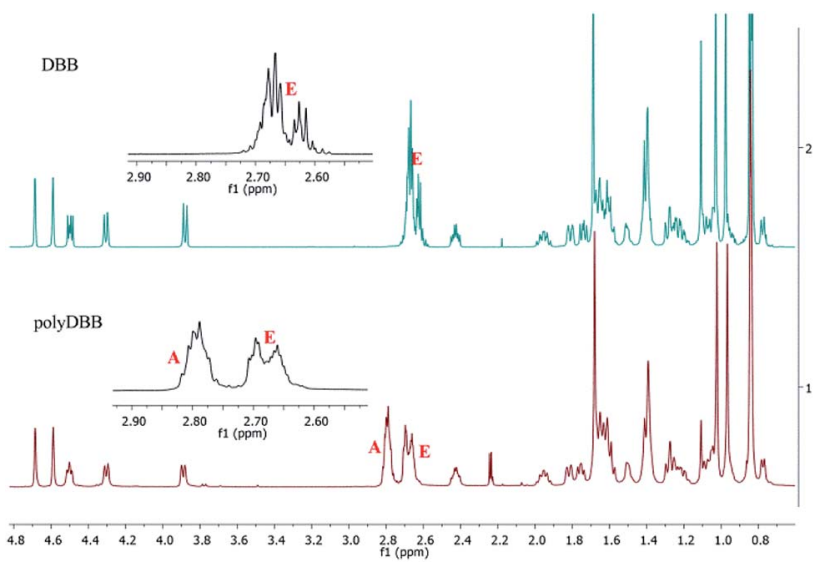

Fig. $5{ }^{1} \mathrm{H}$ NMR spectra of DBB and polyDBB.

using the intensity of the signals of protons at $\delta=4.69,4.59$, $4.50,4.30,3.89 \mathrm{ppm}$ and the intensity of the end groups signals at $\delta=2.18 \mathrm{ppm}$. The ${ }^{13} \mathrm{C}$ NMR (Fig. 6) spectrum of polyDBB
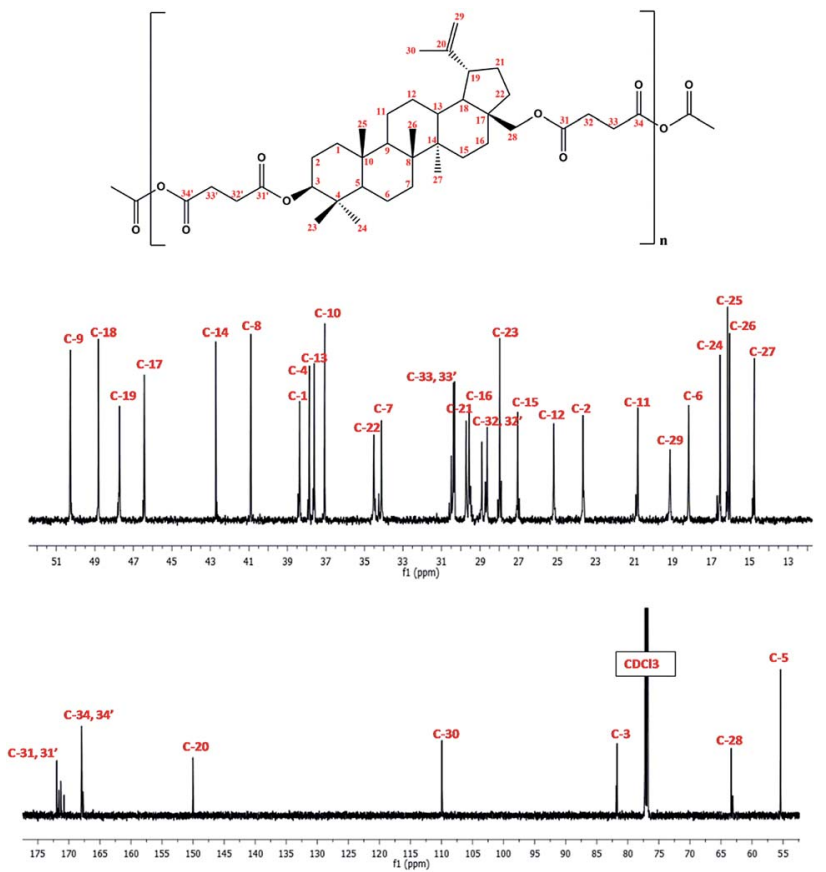

Fig. $6{ }^{13} \mathrm{C}$ NMR spectrum of polyDBB.

showed two different signals assigned to carbonyl carbon atoms in anhydride $(\delta=167.96 \mathrm{ppm})$ and ester groups $(\delta=171.93$ ppm) as well as two different signals of methylene carbon atoms
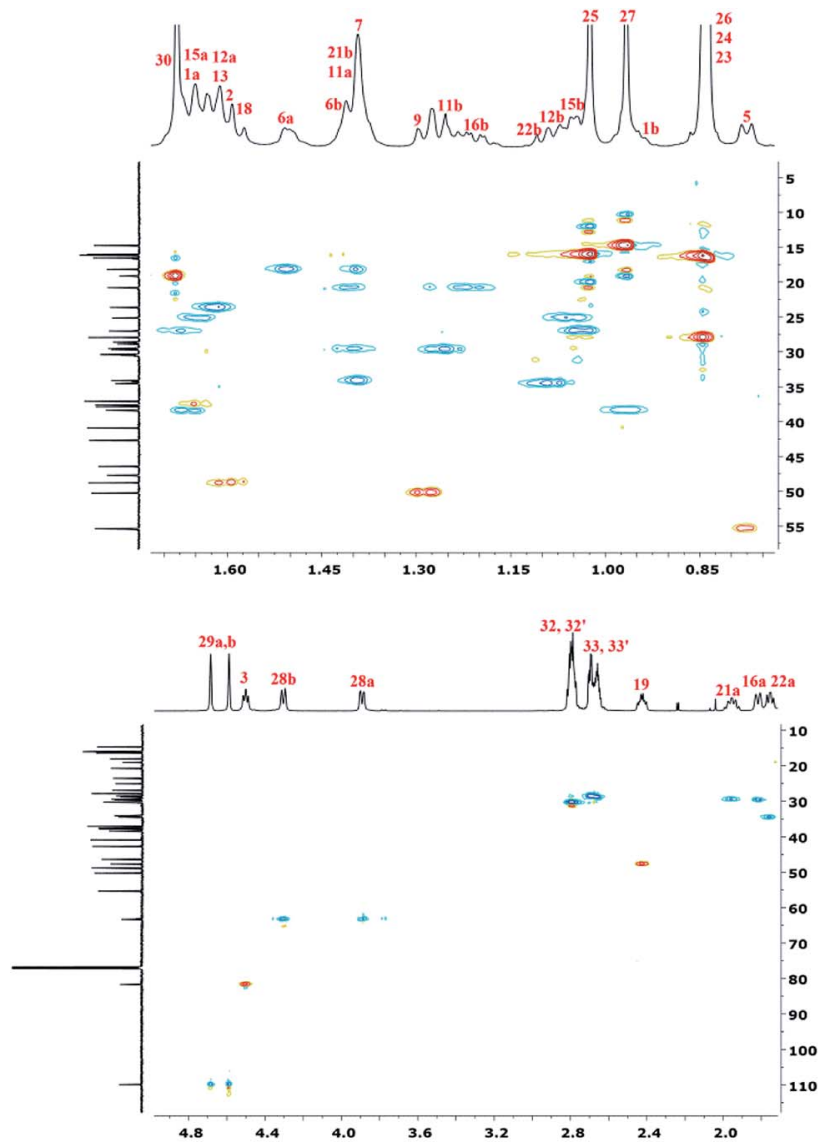

Fig. 7 HSQC NMR spectrum of polyDBB. 
next to ester $(\delta=28.62 \mathrm{ppm})$ and anhydride $(\delta=30.38-30.32$ ppm) groups, respectively. ${ }^{13} \mathrm{C}$ NMR signals were assigned to the relevant polyDBB carbons, but due to the complex structure of polyDBB and the overlapping signals of protons in the rings of betulin, it was impossible to assign all ${ }^{1} \mathrm{H}$ NMR signals to the corresponding protons.

To accurately describe the structure of polyDBB, a twodimensional HSQC spectrum was made (Fig. 7) enabling to assign proton signals to the corresponding carbons and to determine all signals in the ${ }^{1} \mathrm{H}$ NMR spectrum, except for the two methyl groups at carbons C-26 and C-25. This problem was overcome by collecting a COSY spectrum, which confirmed previous arrangements.

\subsection{Hydrolytic degradation and stability of polyDBB}

Hydrolytic degradation of polyDBB, which is of a significant importance for any drug delivery application, was carried out in PBS (pH 7.4) and in distilled water (pH 5.5) at $37^{\circ} \mathrm{C}$, in order to determine the disappearance of anhydride bonds and the weight loss. Additionally, the degradation products that have been dissolved in the supernatant were also tested. ${ }^{1} \mathrm{H}$ NMR spectra of lyophilized residues after different degradation times revealed the presence of disuccinate betulin among the degradation products. This is typical for polyanhydrides, that easily undergo hydrolytic degradation to appropriate diacids. ${ }^{18}$ In case of polyDBB, this diacid is disuccinate betulin and hence it was the only product released during hydrolysis. What is more, no hydrolysis of ester bonds in disuccinate betulin was observed. In the ${ }^{1} \mathrm{H}$ NMR spectra of the degradation products (Fig. 8), the signals at $\delta=3.18 \mathrm{ppm}, \delta=3.33 \mathrm{ppm}$ and $\delta=3.79 \mathrm{ppm}$ assigned to methylene and methine protons next to hydroxyl groups were not observed.

Similar polyanhydride prodrug system, was investigated and described by Uhrich et al., with salicylic acid contained in the backbone of the polymer. Salicylic acid release was depended on aliphatic diacid used as a comonomer in synthesis of the polyanhydride. ${ }^{25,26}$

The degradation rate of polyanhydrides is strongly depended on the kind of diacid used in synthesis and varies from a few days to several years. ${ }^{18,25-27}$ The highly hydrophobic polyanhydrides exhibit surface-eroding properties. ${ }^{26,27}$ Due to the

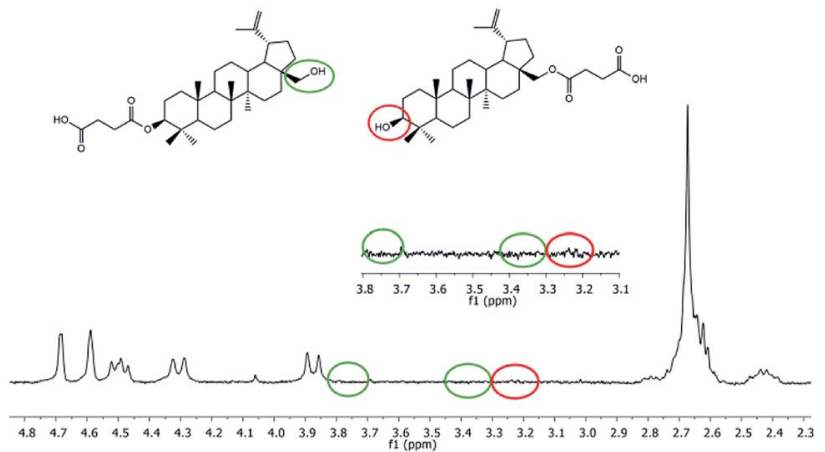

Fig. $8{ }^{1} \mathrm{H}$ NMR spectrum of degradation products (after 14 days of degradation) of polyDBB. strong hydrophobicity of the polyDBB, it degrades relatively slowly (Fig. 9A). After 14 days under physiological conditions the complete disappearance of anhydride bonds was observed, indicating full degradation. The weight loss of sample, however, was only about $20 \%(\mathrm{w} / \mathrm{w})$ after this time, which is supposed to be the effect of the poor solubility of degradation product (DBB) in water.

The stability of polyDBB in air at room temperature was also investigated. As in the case of the hydrolytic degradation study, the amount of anhydride bonds was determined after certain time of keeping the sample in air (Fig. 9B). After 60 days under the testing conditions, more than $50 \%$ of anhydride bonds was still present in the sample, indicating good stability of polyDBB in the air.

\subsection{Cytostatic activity of DBB and polyDBB}

DBB and polyDBB were studied to determine their cytostatic activity against selected cancer cell lines. In these studies, cell lines representing cervix, breast, lung, liver, central nervous system and nasopharynx tumors were used to find concentrations causing inhibition of cell growth in culture by $50 \%\left(\mathrm{IC}_{50}\right)$. HDF cell lines were also used as non-proliferative cells, to compare results from human cancer cell lines and to establish selectivity between cancer and non-cancer cells. Cytarabine was used as the internal standard for methodological evaluation. Actinomycin D, a widely used anticancer agent, was used in this experiment to compare with our compounds and their activity. Actinomycin D has at least two mechanism of action: inhibition of topoisomerases (I and II), and DNA direct intercalation.

(A)

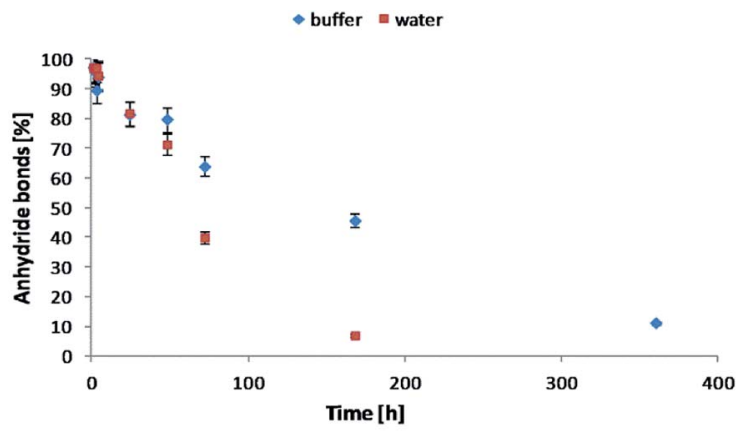

(B)

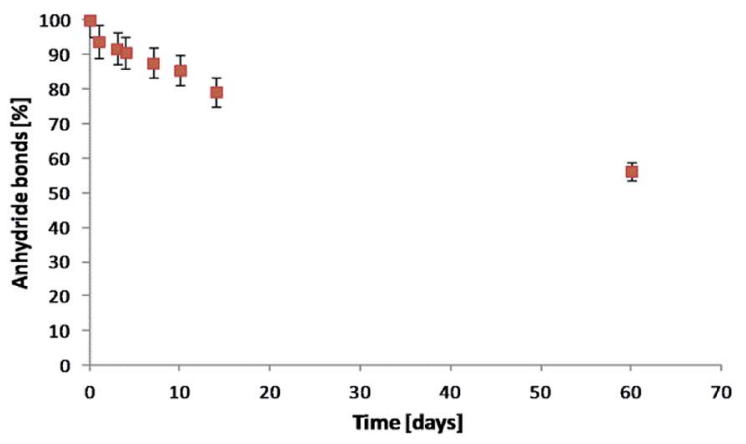

Fig. 9 Anhydride bonds loss during hydrolytic degradation of polyDBB in water and phosphate buffer (A) conducted at $37^{\circ} \mathrm{C}$ and in the air (B) at $25^{\circ} \mathrm{C}$. 
The $\mathrm{IC}_{50}$ values obtained for DBB and polyDBB are listed in Table 2.

Cytostatic tests indicated the effectiveness of DBB and polyDBB in inhibition of growth of cancer cells $\left(\mathrm{IC}_{50}<20 \mu \mathrm{g} \mathrm{mL}{ }^{-1}\right)$, with limited cytotoxicity towards normal cells. DBB showed moderate cytostatic activity against tested cancer cells $\left(\mathrm{IC}_{50}\right.$ in the range of 7.09 to $8.25 \mu \mathrm{g} \mathrm{mL}{ }^{-1}$ ). Biological activity of betulin disuccinate, was described in literature,,$^{5,13-17}$ and was further confirmed by our study. $\mathrm{IC}_{50}$ values calculated for polyDBB were higher than those determined for DBB, what might indicate milder cytostatic activity of the polyanhydride. Nevertheless, it must be emphasized that the anti-cancer activity of polyDBB depends on the degree of hydrolytic degradation of polymer and on the amount of DBB released. PolyDBB is a polymeric prodrug system in which the drug is chemically incorporated into the polymer backbone, with the actual active agent (DBB) becoming available as the polymer degrades. The cytostatic activity was determined after $72 \mathrm{~h}$, at which polyDBB was degraded to elute DBB. During the 72 hour hydrolytic degradation the sample losses around $16 \%$ of their initial mass (Fig. 10A), releasing equivalent amount of DBB. What is important, DBB was the only degradation product that was found in the supernatant. Hence, polyDBB was shown to serve as a degradation-based delivery system for DBB, thus having long lasting cytostatic effect when compared to DBB. Cytostatic effects of the polymeric derivatives of betulin can be further modified by copolymerization of DBB with different diacids, allowing to optimize the degradation rate and tailor the period of cytotoxicity. For example, copolymerization of $\mathrm{DBB}$ with polyethylene glycol (PEG600) was found to accelerate the degradation process (Fig. 10), resulting in a significant increase in $\mathrm{IC}_{50}$ values determined after $72 \mathrm{~h}$ (Table 2).

Copolymer of DBB and PEG600 (polyDBB_PEG600_40), was obtained accordingly to the procedure described for polyDBB. $40 \mathrm{wt} \%$ of $\mathrm{DBB}$ was replaced by dicarboxylic derivatives of PEG600. Due to the increase in the hydrophilicity, polyDBB_PEG600_40 degraded faster (Fig. 10) than polyDBB losing over $50 \%$ of their initial weight and thus releasing more DBB after $72 \mathrm{~h}$.

\subsection{Microspheres and nanospheres from polyDBB}

PolyDBB was applied for the preparation of micro- and nanospheres by means of an emulsion $(\mathrm{O} / \mathrm{W})$ solvent evaporation

(A)
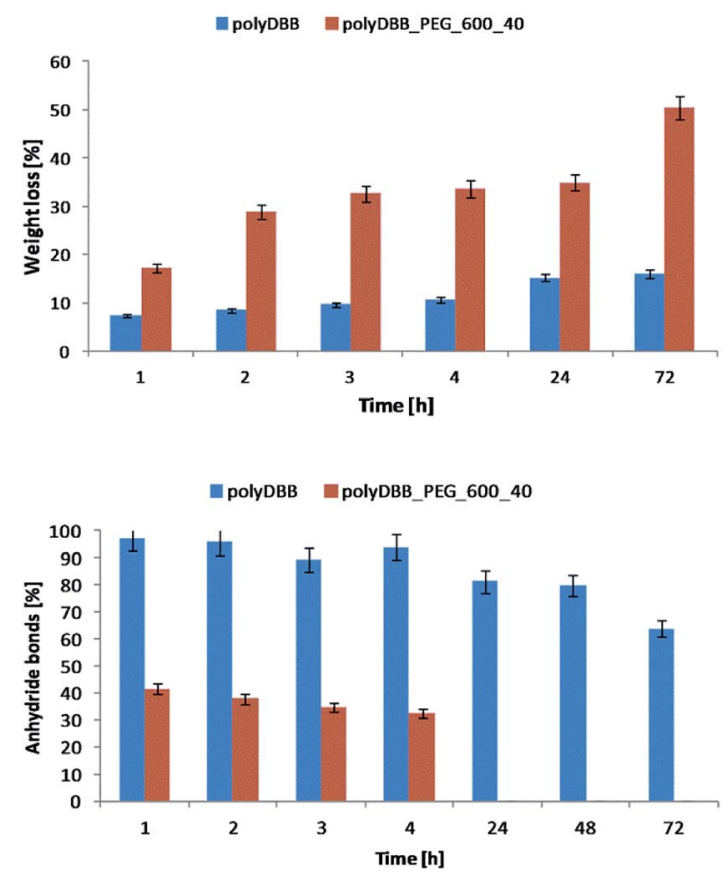

Fig. 10 The comparison of hydrolytic degradation of polyDBB and polyDBB_PEG600_40 (A) mass loss and (B) anhydride bonds loss.

technique using poly(vinyl alcohol) as stabilizing agent. By changing the speed of homogenization, it was possible to form smooth microspheres with diameters of 20-30 $\mu \mathrm{m}$ (3000 rpm, Fig. 11A) and 1-3 $\mu \mathrm{m}$ (18 $000 \mathrm{rpm}$, Fig. 11B). When the ultrasounds were used, it was possible to form polyDBB nanospheres (Table 3). Two fractions of polymer nanospheres were obtained, those having the diameters of approx. 800-900 nm (obtained

A

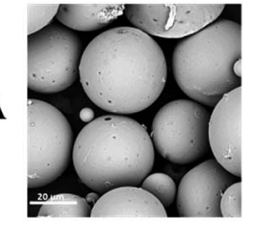

B

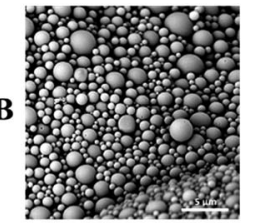

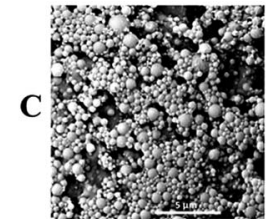

Fig. 11 SEM images of polyDBB microspheres obtained by using homogenization speeds of $3000 \mathrm{rpm}(\mathrm{A})$ and $18000 \mathrm{rpm}$ (B) and polyDBB nanospheres (C).

Table 2 Cytostatic activity of DBB and polyDBB against various cancer cell lines as well as a normal control (HDF), expressed as IC ${ }_{50}{ }^{a}$

\begin{tabular}{|c|c|c|c|c|c|c|c|}
\hline \multirow[b]{2}{*}{ Compound } & \multicolumn{7}{|c|}{$\underline{\text { Cytostatic activity } \mathrm{IC}_{50}\left[\mu \mathrm{g} \mathrm{mL}{ }^{-1}\right]}$} \\
\hline & HeLa & MCF-7 & A-549 & U-87 MG & $\mathrm{KB}$ & HepG2 & $\mathrm{HDF}$ \\
\hline DBB & $8.25 \pm 0.81$ & $7.26 \pm 0.79$ & $7.09 \pm 0.01$ & $7.37 \pm 0.26$ & $7.17 \pm 0.93$ & $8.02 \pm 0.04$ & $14.80 \pm 0.06$ \\
\hline PolyDBB & $16.23 \pm 0.72$ & $13.38 \pm 0.06$ & $16.19 \pm 0.31$ & $16.07 \pm 0.02$ & $17.81 \pm 0.03$ & $15.93 \pm 0.12$ & $27.13 \pm 0.01$ \\
\hline PolyDBB_PEG ${ }^{b}$ & $9.03 \pm 0.51$ & $9.79 \pm 0.02$ & $8.62 \pm 0.19$ & $9.07 \pm 0.09$ & $9.37 \pm 0.02$ & $9.84 \pm 0.91$ & $17.22 \pm 0.88$ \\
\hline Cytarabine $^{c}$ & $1.40 \pm 0.08$ & - & $1.17 \pm 0.21$ & $1.03 \pm 0.25$ & $0.95 \pm 0.02$ & $1.49 \pm 0.04$ & $1.94 \pm 0.01$ \\
\hline Actinomycin $^{c}$ & $1.13 \pm 0.01$ & - & $1.03 \pm 0.83$ & $0.92 \pm 0.59$ & $1.07 \pm 0.05$ & $1.19 \pm 0.02$ & $2.28 \pm 0.11$ \\
\hline
\end{tabular}

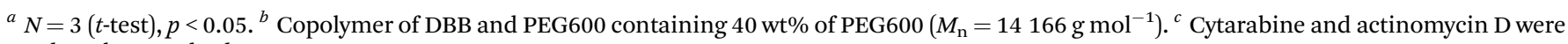
used as the standard. 
after the first centrifugation at $5000 \mathrm{rpm}$ for $5 \mathrm{~min}$ ) and of approx. 400-500 nm (obtained after the second centrifugation at $8000 \mathrm{rpm}$ for $3 \mathrm{~min}$ ) (Fig. 11C), both spherical in shape and having smooth surface. Nanospheres from the second fraction, however, had the tendency to agglomerate. This tendency, as well as the microsphere diameters, could be reduced by the copolymerization of DBB with PEG. The results will be published separately.

Because the polyDBB are hydrolytically unstable, it was necessary to quantify the degree of hydrolytic degradation that occurs during the micro- or nanospheres fabrication. For this purpose, the molecular weight (GPC) and anhydride bonds content $\left({ }^{1} \mathrm{H}\right.$ NMR) were determined for neat polymer (before microspheres fabrication) and polymer after microspheres preparation. The molecular weight loss, as well as the disappearance of anhydride bonds, were observed for all microspheres, but the degree of hydrolysis was the less significant the larger the microspheres were obtained. For the microspheres with diameters of $20-30 \mu \mathrm{m}$ (3000 rpm), 20\% reduction of $M_{\mathrm{n}}$ and $5 \%$ disappearance of anhydride bonds were observed, after microparticles formulation. The process of hydrolytic degradation of polymers was more significant when small microspheres $\left(D_{\mathrm{n}}=1-3 \mu \mathrm{m}\right)$ or nanospheres were produced. It is due to an increased surface area available for contact with water. Such dependence is characteristic for polyanhydrides, which undergo hydrolytic degradation at the surface. Fig. 9 shows ${ }^{1} \mathrm{H}$ NMR spectra (in range of ester and anhydride groups) and GPC chromatograms of polyDBB before and after nanospheres preparation. The disappearance of anhydride bonds was less than $15 \%$, but the almost $60 \%$ reduction of $M_{\mathrm{n}}$ was observed after nanospheres preparation. $M_{\mathrm{n}}$ of polyDBB after nanospheres preparation was equal to $3500 \mathrm{~g} \mathrm{~mol}^{-1}$, compared to the neat polymers with $M_{\mathrm{n}}=8496 \mathrm{~g} \mathrm{~mol}^{-1}$. In the GPC chromatogram of polyDBB after nanospheres preparation (Fig. 12), the low molecular weight fraction with $M_{\mathrm{n}}=770 \mathrm{~g} \mathrm{~mol}^{-1}$ was observed, besides the main fraction with $M_{\mathrm{n}}=8507 \mathrm{~g} \mathrm{~mol}^{-1}$. The molecular weight of the main fraction is on the same level as the molecular weight of neat polymers, whereas the molecular weight of the second fraction corresponds approximately to DBB. This confirmed that polyDBB undergoes hydrolytic degradation from the end of the chain to release DBB as degradation products.

Table 3 Size and size distribution of micro- and nanospheres calculated from optical microscope and SEM images

\begin{tabular}{|c|c|c|c|c|c|c|}
\hline \multirow[b]{2}{*}{ homogenizer rpm } & \multicolumn{3}{|c|}{ Optical microscope } & \multicolumn{3}{|l|}{ SEM } \\
\hline & $D_{\mathrm{n}}[\mu \mathrm{m}]$ & $S$ & $D_{\mathrm{v}} / D_{\mathrm{n}}$ & $D_{\mathrm{n}}[\mu \mathrm{m}]$ & $S$ & $D_{\mathrm{v}} / D_{\mathrm{n}}$ \\
\hline 3000 & 23.81 & 4.56 & 1.11 & 27.25 & 10.93 & 1.29 \\
\hline 18000 & 3.23 & 0.95 & 1.24 & 1.73 & 1.14 & 2.59 \\
\hline Ultrasound $^{a}$ & - & - & - & 0.898 & 0.46 & 1.86 \\
\hline Ultrasound $^{b}$ & - & - & - & 0.417 & 0.55 & 3.85 \\
\hline
\end{tabular}

${ }^{a}$ The first fraction obtained after the first centrifugation (5000 rpm for 5 min). ${ }^{b}$ The second fraction obtained after the second centrifugation (8000 rpm for $3 \mathrm{~min}$ ).

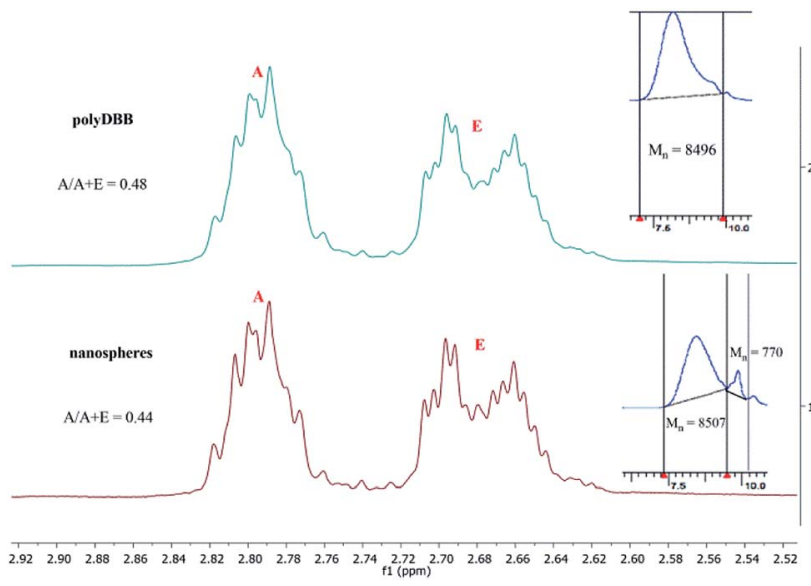

Fig. $12{ }^{1} \mathrm{H}$ NMR spectra (ester and anhydride groups region) and GPC chromatograms of polyDBB (A) before and (B) after nanospheres preparation.

The possibility of making micro- and nanospheres from polyDBB indicates the potential applicability of this polymer as a controlled drug release system. As such, it possesses promisingly suitable and controllable degradation rate, making it a potentially suitable drug delivery system for DBB. Similar delivery systems of betulin or betulin derivatives have recently been investigated, and described in literature. Such systems were proposed in forms of e.g. nanoemulsion, ${ }^{28}$ nanoparticles, ${ }^{29}$ PLA nanovectors ${ }^{30}$ or micelles. ${ }^{31}$ It has been found that incorporating betulin substance into a nanosystem could significantly increase dissolution rate and/or its bioavailability. ${ }^{28-31}$ However, in all of the described nanosystems, betulin derivatives were physically entrapped in the carrier substance. Therefore, their release was mainly controlled by diffusion and could not be easily adjusted. In case of polyDBB, betulin disuccinate is chemically incorporated into the polymer backbone itself and becomes available as the polymer degrades. This design allows for a maximum amount of drug to be incorporated within the polymer structure, and its release to be controlled by the degree of degradation. Such systems are usually more stable, exhibit a smaller burst effect and exhibit better release characteristics. ${ }^{18,32,33}$

PolyDBB spheres may be also considered as vehicles for another biologically active compounds. The possibility of tailoring the size of the particles makes it possible to target for different forms of administration, including inhalation or intravenous injection (nanospheres), as well as intramuscular injection or implantation (microspheres).

\section{Conclusions}

In this work, a new polyanhydride, polyDBB, based on a betulin derivative was obtained and thoroughly characterized. Under physiological conditions $\left(37^{\circ} \mathrm{C}, \mathrm{pH}=7.4\right.$ or $\left.\mathrm{pH}=5.5\right)$, polyDBB was shown to undergo hydrolytic degradation to form betulin disuccinate, whose biological activity is known and confirmed. 
It was shown that polyanhydride can be fabricated in a form of micro- or nanospheres, being easily administrated by injection or inhalation. In this way, polyDBB serves as a promising degradation rate controlled drug delivery system for either DBB or other cytostatic agents.

\section{Conflicts of interest}

The authors declare no conflict of interest.

\section{Notes and references}

1 S. Cai, T. R. Bagby and M. L. Forrest, Ther. Delivery, 2011, 2, 1467-1484.

2 S. A. Stewart, J. Dominguez-Robles, R. F. Donnelly and E. Larraneta, Polymers, 2018, 10, 1379-1403.

3 S. Alakurtti, T. Mäkelä, S. Koskimies and J. Yli-Kauhaluoma, Eur. J. Pharm. Sci., 2006, 29, 1-13.

4 S. Jager, H. Trojan, T. Kopp, M. N. Laszczyk and A. Scheffler, Molecules, 2009, 14, 2016-2031.

5 J. Patočka, J. Appl. Biomed., 2003, 1, 7-12.

6 A. Muhammad, R. M. Carlson, P. Krasutsky and M. Karim, J. Microbiol. Biotechnol., 2004, 14, 1086-1088.

7 C. M. Wang, K. L. Yeh, S. J. Tsai, Y. L. Jhan and C. H. Chou, Molecules, 2017, 22, 2119-2132.

8 J. L. C. Sousa, C. S. R. Freire, A. J. D. Silvestre and A. M. S. Silva, Molecules, 2019, 24, 355.

9 J. Jeromenok, W. Böhlmann, M. Antonietti and J. Weber, Macromol. Rapid Commun., 2011, 32, 1846-1851.

10 J. Zhao, H. Schlaad, S. Weidner and M. Antonietti, Polym. Chem., 2011, 1763-1768.

11 J. Jeromenok, W. Böhlmann, C. Jäger and J. Weber, ChemistryOpen, 2013, 2, 17-20.

12 M. Okada, K. Suzuki, Y. Mawatari and M. Tabata, Eur. Polym. J., 2019, 113, 12-17.

13 I. C. Sun, H. K. Wang, Y. Kashiwada, J. K. Shen, L. M. Cosentino, C. H. Chen, L. M. Yang and K. H. Lee, J. Med. Chem., 1998, 41, 4648-4657.
14 P. A. Krasutsky, US Pat., WO2002026761 A1, 2002.

15 P. A. Krasutsky, US Pat., 20020119935 A1, 2002.

16 S. Chowdhury, T. Mukherjee, S. R. Chowdhury, S. Gupta, S. Mukhopadhyay, P. Jaisankar and H. K. Majumder, Antimicrob. Agents Chemother., 2014, 58, 2186-2201.

17 R. A. Pegova, et al., Medical Almanac, 2015, 3, 216.

18 A. J. Domb, N. Kumar, and A. Ezra. Biodegradable polymers in clinical use and clinical development. Wiley\&Sons Inc., Hoboken, New Jersey, USA, 2011.

19 K. Jaszcz, Macromol. Symp., 2007, 254, 109-116.

20 K. Jaszcz, M. Śmiga-Matuszowicz and J. Łukaszczyk, React. Funct. Polym., 2008, 68, 351-360.

21 K. Jaszcz, Int. J. Polym. Mater. Polym. Biomater., 2014, 63, 97106.

22 P. Skehan, et al., J. Natl. Cancer Inst., 1990, 82, 1107-1112.

23 S. Q. Tian, K. Lu, G. Z. Fang, S. Y. Han and Q. Ai, Chem. Ind. Forest Prod., 2007, 27, 77-80.

24 S. Q. Tian, K. Lu, G. Z. Fang, S. Y. Han and Q. Ai, J. Beijing For. Univ., 2009, 31, 108-111.

25 A. Prudencio, R. C. Schmeltzer and K. Uhrich, Macromolecules, 2005, 38, 6895-6901.

26 K. Whitaker-Brothers and K. Uhrich, J. Biomed. Mater. Res., Part A, 2006, 76, 470-479.

27 A. Göpferich and J. Tessmar, Adv. Drug Delivery Rev., 2002, 54, 911-926.

28 C. A. Dehelean, S. Feflea, S. Ganta and M. Amiji, J. Biomed. Nanotechnol., 2011, 7, 317-324.

29 X. H. Zhao, et al., Drug Deliv., 2014, 21, 467-479.

30 R. Yadav, D. Kumar, A. Kumara and S. Kumar Yadav, Biotechnol. Lett., 2016, 38, 259-269.

31 K. Jelonek, et al., Indones. J. Pharm., 2019, 557, 43-52.

32 Q. Sun, J. Wang, M. Radosz, and Y. Shen, Functional Polymers for Nanomedicine, in Functional Polymers for Nanomedicine, ed. Y. Shen, The Royal Society of Chemistry, 2013.

33 S. Dragojevic, J. Su Ryu and D. Raucher, Molecules, 2015, 20, 21750-21769. 